\title{
The role of psychological capital in the relationship between authentic leadership and work engagement
}

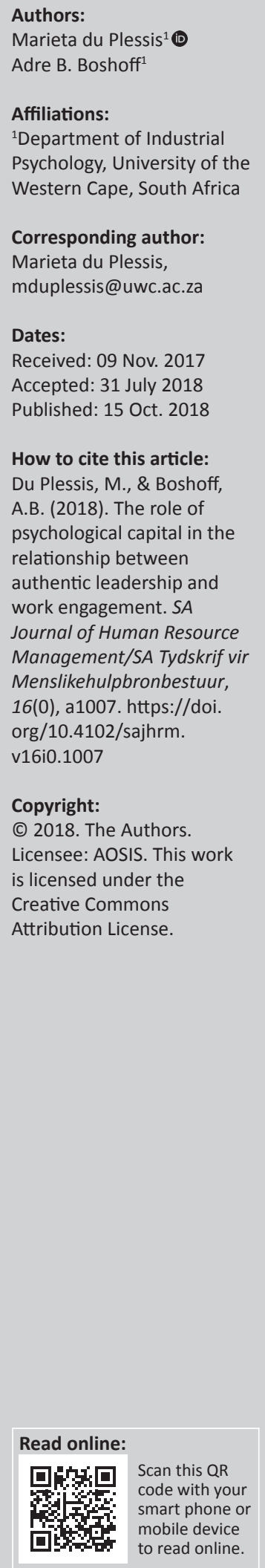

Orientation: The focus on positive psychology in the workplace includes interest in engagement of employees and the conditions and/or characteristics that explain variance in engagement levels.

Research purpose: Psychological capital (PsyCap) can be used as a substitute or enhancer for leadership in the development of work engagement in cases where the individual has a high level of PsyCap.

Motivation for the study: With work engagement becoming increasingly critical to the competitiveness of today's organisations, there is a need to better understand the role of leadership and psychological strengths that support work engagement among employees.

Research approach/design and method: In the quantitative study (on the responses of 647 managers from a national private healthcare organisation), the mediating and moderating role of psychological capital (PsyCap) on the relationship between authentic leadership and work engagement was tested.

Main findings: Psychological capital partially mediated the relationship between authentic leadership and work engagement. Similarly, PsyCap was also a moderator of the relationship, although the main effects remained significant.

Practical/managerial implications: Organisations and leaders should focus on developing a high level of PsyCap within their followers in order to retain high levels of work engagement.

Contribution/value-add: The role of PsyCap in the leadership-engagement relationship indicates that individuals can draw from their PsyCap to improve work engagement.

\section{Introduction}

The number of studies on engagement of employees has increased rapidly over the past two decades (Bakker \& Albrecht, 2018). From a workplace perspective, engagement of employees is a desirable characteristic of the workforce in the creation of peak performance (Bakker, Demerouti, \& Sanz-Vergal, 2014). Even though the engagement of more than a million employees has been studied (Bargagliotti, 2012), it is anticipated that employee engagement will remain an important concern for countries and organisations who seek to increase labour productivity (Gallup, 2013). Not only does engagement enhance important organisational outcomes, it also has positive effects on the psychological well-being of employees (Robertson \& Cooper, 2009). Thus, from a psychological perspective, the growth and interest in the field of Positive Psychology, with its focus on happiness, human strengths and optimal functioning (Seligman \& Csikszentmihalyi, 2000), gave impetus to the interest in engagement. Seligman (2011) proposed that engagement is regarded as one of the routes to happiness as well as one of the dimensions of human flourishing.

Leaders play an important role in creating a climate of engagement within the organisation (Kahn \& Heaphy, 2014). When leaders support, encourage and develop their employees, employees are more likely to have a high level of engagement (Harter \& Adkins, 2015). Harter and Adkins (2015) proposed that up to $70 \%$ of the variance in engagement scores can be ascribed to leader behaviours. Against the background of positive organisational behaviour, Luthans and Avolio (2003) conceptualised a positive form of leadership, which is termed 'authentic leadership'. Authentic leaders have a well-developed capacity to process information about themselves (including their values, beliefs, goals and feelings); they have clarity regarding their personal identity and have an ability to adjust their leadership behaviours to the needs and preferences of their followers, while still acting in accordance to their personal identity (Chan, Hannah, \& Gardner, 2005).

An important part of authentic leadership includes the personal identification of the employee with the leader. Through this identification, authentic leaders influence the thinking and behaviour 
of members of the organisation (Sparrowe, 2005). The positive modelling of authentic leaders fosters internalised regulation processes among followers, which contribute to greater levels of well-being and engagement (Deci, Connell, \& Ryan, 1989). Avolio and Gardner (2005) state that these exchanges would possibly assist individuals to find meaning and purpose in their jobs and craft jobs that best suit their strengths, and the leader would also encourage individuals to persist in their work-related efforts. These actions may result in enhancing employees' vigour, dedication and absorption in their work. Leaders furthermore have an influence on their followers' positive psychological states and psychological capital (PsyCap) by increasing followers' self-confidence and creating hope, optimism and resilience (Ilies, Morgeson, \& Nahrgang, 2005; Mäkikangas, Feldt, Kinnunen, \& Mauno, 2013).

Avolio and Mhatre (2012) suggest that, although research on authentic leadership continues to grow, researchers should also explore a broader range of mediating and moderating mechanisms in an attempt to explain the authentic leadership construct and its relationship with other organisational variables. For instance, Hsieh and Wang (2015) reported that employee trust mediates the relationship between authentic leadership and work engagement. It should be considered that not all employees' needs are the same and that employees also have psychological capacities that could influence how they interpret and integrate their leader's supportive behaviours into their work behaviours. Followers who are led by authentic leaders feel more efficacy and take greater ownership of their work, as well as being more resilient and hopeful (Rego, Sousa, Marques, \& Pina e Cunha, 2012). Similarly, employees who have more personal resources (including self-efficacy, optimism and resilience) have higher levels of work engagement (Mäkikangas et al., 2013). However, authors have suggested that specific leadership styles may be more effective for some followers than for others (Conger \& Kanungo, 1998; Pillai \& Meindl, 1998), and hence the followers' characteristics would act as a moderator of the influence of the leader. It may be valuable to explore the role of PsyCap because of its predictive properties in explaining peak performance.

\section{Purpose}

PsyCap could intervene in the relationship between broad contextual and leadership factors, such as authentic leadership (Avey, Wernsing, \& Luthans, 2008), and individual outcomes, such as organisational citizenship behaviour and work performance (Luthans, Norman, Avolio \& Avey, 2008; Norman, Avey, Nimnicht, \& Pigeon, 2010). As PsyCap seems to be instrumental in facilitating the impact of a positive organisational context on various desirable outcomes (Youssef \& Luthans, 2012), it was proposed that PsyCap mediates the relationship between authentic leadership and work engagement. It was further proposed that PsyCap could be a mechanism through which individuals adapt their responses to attain higher levels of work engagement. High PsyCap levels offer employees cognitive (i.e. efficacy), motivational (i.e. hope) and other positive psychological strengths (such as resilience and optimism) (Sweetman, Luthans, Avey \& Luthans, 2011), which may assist them in immersing themselves fully in their work apart from the influence of leadership support. Thus, the moderating effect of PsyCap on the relationship between authentic leadership and work engagement was studied.

\section{Literature review}

\section{Authentic leadership}

Luthans and Avolio (2003) conceptualised a positive form of leadership, which is termed 'authentic leadership'. Authentic leadership draws from both positive psychological capacities of the leader and a highly developed organisational context. These factors, in turn, result in greater self-awareness and self-regulated positive behaviours on the part of the leader. Authentic leadership comprises self-awareness, relational transparency, internalised moral perspective and balanced processing (Avolio \& Mhatre, 2012). Self-awareness is defined as an individual's accurate knowledge of his or her own strengths and weaknesses and the way one makes sense of the world. Relational transparency involves appropriate selfdisclosure and a genuine presentation of oneself to other people. Balanced processing includes the collection and use of objective, relevant information and balancing this with beliefs that are held, even if the objective information challenges prior beliefs. An internalised moral perspective would influence an individual to act with self-determination and self-regulation, rather than acting in accordance with situational demands (Avolio, Walumbwa, \& Weber, 2009).

The theory of authentic leadership emphasises positive and developmental interactions between leaders and followers (Woolley, Caza, \& Levy, 2011). Avolio, Gardner, Walumbwa, Luthans and May (2004) proposed a theoretical framework that links authentic leadership to the attitudes and behaviours of followers. According to Avolio et al. (2004), authentic leaders influence their followers' attitudes and behaviours by creating a sense of personal and social identification and setting high moral values and standards. For instance, authentic leaders would use role modelling to display high moral standards to their followers in order for the followers' values and beliefs to become more similar to those of the leaders (Gardner, Avolio, Luthans, May, \& Walumbwa, 2005). Another example would be the leader's concern regarding a follower's transparent and genuine discussion of his or her own vulnerabilities, thereby emphasising the constant focus on growth and development of the follower as well as the leader (Avolio et al., 2004).

Followers' personal and social identification with authentic leaders has been shown to lead to higher levels of hope (Snyder, Irving, \& Anderson, 1991) and trust (Avolio et al., 2004; Chan et al., 2005; Gardner et al., 2005). Hsieh and Wang (2015) reported that employee trust mediates the relationship between the leader's level of authentic leadership and follower work engagement. Furthermore, positive emotions 
(Avolio et al., 2004; Chan et al., 2005) and positive states (Luthans, Youssef, \& Avolio, 2007), including higher levels of PsyCap (Munyaka, Boshoff, Pietersen, \& Snelgar, 2017), have also resulted from identification of followers with leaders.

Jensen and Luthans (2006) reported that employee perceptions of authentic leadership were the strongest predictor of employee job satisfaction, organisational commitment and work happiness. Further empirical research has demonstrated a positive relationship between the frequency with which authentic leadership is exhibited and the job performance of followers (Peterson, Walumbwa, Avolio, \& Fredrickson, 2010, cited in Cameron \& Spreitzer, 2012).

Authentic leadership was found to play an important role in the PsyCap development of the follower (Luthans, Avolio, Avey \& Norman, 2007; Woolley et al., 2011). It has also been empirically established that PsyCap and a positive organisational context are antecedents of authentic leadership development (Petersen, 2015). Hence, it becomes clear that authentic leadership theory ascribes an important role to the PsyCap of leaders and followers.

\section{Psychological capital}

Bearing in mind the criteria for constructs to be included in PsyCap (Luthans, 2002), the positive constructs of efficacy, hope, optimism and resilience met the inclusion criteria (Luthans, Youssef, \& Avolio, 2007). These writers termed the combination of these positive constructs as PsyCap. PsyCap is defined as follows:

An individual's positive psychological state of development that is characterised by: (1) having confidence (self-efficacy) to take on and put in the necessary effort to succeed at challenging tasks; (2) making a positive attribution (optimism) about succeeding now and in the future; (3) persevering toward goals, and, when necessary, redirecting paths to goals (hope) in order to succeed; and (4) when beset by problems and adversity, sustaining and bouncing back and even beyond (resilience) to attain success. (p. 3)

Apart from the importance of each of the four constructs, the synergistic phenomenon of overall PsyCap has been shown to have a higher correlation with performance outcomes than any of the four individual constructs (Luthans, Avolio, et al., 2007). This finding is consistent with Hobfall's (2002) psychological resource theory, which suggests that some constructs are best understood as indicators of broader underlying factors as they may interact synergistically to produce differentiated behaviours over time and different contexts. As a result, PsyCap is classified as a second-order (or higher-order) construct that includes the first-order factors of efficacy, hope, resilience and optimism but also the synergy and shared variance between these four dimensions (Avey, Reichard, Luthans, \& Mhatre, 2011; Luthans \& Youssef-Morgan, 2017).

A meta-analysis of PsyCap revealed that a number of studies have tested the relationship between PsyCap and various employee attitudes, behaviours and performance (Avey et al., 2011). These writers argue that individuals who possess a high level of PsyCap are likely to be energised and produce effort that leads to higher levels of performance over extended periods of time. PsyCap has been positively correlated to employee performance and satisfaction (Luthans, Avolio et al., 2007), as well as organisational commitment and psychological well-being at work (Avey et al., 2011). Selfefficacy, hope, resilience and optimism, as well as overall PsyCap, have also been shown to have positive relationships with work engagement (Simons \& Buitendach, 2013). PsyCap has also been found to mediate the relationship between a supportive organisational climate and performance (Luthans et al., 2008). Furthermore, Huang and Luthans (2014) reported that PsyCap mediated the relationship between learning goal orientation and creativity.

Luthans, Luthans and Luthans (2004) reported that, as with human and social capital, PsyCap may be developed and used in the workplace. PsyCap capacities are psychological states, as opposed to fixed traits, and are therefore open to development through methods such as role modelling, social persuasion, mastery experiences or performance attainments (Luthans et al., 2004). By utilising these development techniques, leaders may have a significant role to play in the development of the PsyCap of their employees.

\section{Work engagement}

Schaufeli and Bakker (2003) explain work engagement as a positively satisfying, work-related state of mind that is exemplified by vigour, absorption and dedication. Bakker and Demerouti (2008) state that vigour is characterised by high energy levels and mental resilience while working, whereas absorption signifies being fully concentrated during one's work, with time passing quickly and difficulty being experienced in separating oneself from work. Dedication encompasses being involved in one's work and experiencing significance, enthusiasm, inspiration, pride and challenge.

In further exploring the work engagement construct, it is important to stress that employees' psychological presence in their roles is still at the core of the work engagement construct. Work engagement is believed to be rooted in the theory of authenticity. Authenticity is based on the belief that there can be value in displaying one's whole self that can be utilised to the benefit of work (Rothbard \& Patil, 2012). Authentic leadership helps followers to satisfy their own needs, develop themselves and set goals that are in concordance with their own values and beliefs (Gardner et al., 2005).

Studies have demonstrated a positive relationship between work engagement and performance (Cameron \& Spreitzer, 2012). Work engagement has been linked to increased organisational citizenship behaviours (Rich, LePine, \& Crawford, 2010), enhanced overall performance, high levels of job satisfaction and reduced levels of turnover intention (Bakker \& Demerouti, 2008).

With regard to the antecedents of work engagement, studies have shown that personal resources such as self-efficacy, 
optimism (Xanthopoulou, Bakker, Demerouti, \& Schaufeli, 2007) and resilience (Bakker, 2009) are important antecedents of work engagement. These personal resources assist engaged employees to control and impact their work environment in a positive manner (Alesandri, Consiglio, Luthans, \& Borgogni, 2018; Luthans et al., 2008). Self-efficacy, optimism and resilience are described as dimensions of PsyCap, and hence it can be deducted that PsyCap could also be an antecedent of work engagement. The proposed link was tested in an empirical study by Simons and Buitendach (2013), who confirmed the relationship between dimensions of PsyCap and work engagement. Authentic leadership has also been shown to significantly predict work engagement (Penger \& Černe, 2014). Moreover, Giallonardo, Wong and Iwasiw (2010) found higher levels of work engagement when employees perceived authentic leadership behaviour in their leader.

Low levels of engagement have been found in many countries (Robertson \& Cooper, 2010), including South Africa (Rothmann, 2017). Maslach, Schaufeli and Leiter (2001) theorised that the impact of the changing world of work is demonstrated in the expectations imposed on employees. These expectations include expending more time and effort and possessing greater skills and flexibility, while the organisation, on the other hand, is offering less in terms of career opportunities, employment and job security. There is also a general lack of supportive leadership behaviours to assist employees to deal with the job demands they face.

Dissatisfied employees are not committed to an organisation and they are also frequently absent from work in an attempt to cope with or escape from the high work demands (Rothmann, 2017). Organisations with a disengaged workforce may experience severe financial constraints and also lack the competitive edge to survive in the market. It is therefore important for management to focus on ways in which to enhance those aspects of the job that will make employees feel energetic, dedicated and engaged in their work (Mostert \& Rathbone, 2001). For the purpose of the present study, the possible influence of PsyCap on the hypothetical relationship between authentic leadership and work engagement was explored.

\section{Method}

The research design was quantitative in nature and a survey was used to collect the empirical data. A composite questionnaire containing the Utrecht Work Engagement Scale (UWES) (Schaufeli \& Bakker, 2003), PsyCap questionnaire (PCQ) (Luthans et al., 2007) and the Authentic Leadership Questionnaire (ALQ) (Walumbwa, Avolio, Gardner, Wernsing, \& Peterson, 2008) was electronically completed by 647 managers from a national organisation in the healthcare industry in South Africa.

\section{Research procedure}

The sample for the study was selected through purposive sampling. The requirements that were set for participation in the study were access to a computer and the Internet, and acceptable English literacy, as the questions required respondents to be able to differentiate between fine nuances of behaviour described in words. Employees from all branches of the organisation were included. Eight hundred and fifty-five members of the organisation met these characteristics and were invited to respond to the survey. After the process of data gathering, 670 responses were recorded. However some of these responses were incomplete and had to be excluded from the sample. Therefore, the survey response rate of usable responses was calculated as $76 \%(n=647)$.

\section{Participants}

The sample consisted mostly of female (77\% of the sample) and Afrikaans-speaking (66\%) respondents. Further to this, the largest proportion of the sample was managers $(81 \%)$. The respondents' ages ranged from 25 to 63 , with an average age of 45 years $(S D=8.08)$. Although some respondents were quite new to the organisation, the mean tenure of the respondents were 11 years $(S D=6.197)$. The mean reporting period to current manager of 4 years $(S D=4.046)$ also indicates a fairly stable workforce at the managerial level.

\section{Measurement instruments}

The Utrecht Work Engagement Scale (UWES) items are scored on a seven-point Likert scale $(0=$ 'never' to $6=$ 'always'). Previous South African studies reported scores from the UWES to have good internal consistency reliability ranging from 0.78 for vigour and 0.89 for dedication to 0.78 for absorption (Storm \& Rothmann, 2003). Using the UWES as unidimensional, Laba and Geldenhuys (2016) reported a Cronbach's alpha reliability of 0.90 . The internal reliability of scores from the unidimensional UWES in the present study sample was 0.92 .

The PCQ consists of 24 items to measure the four dimensions, namely self-efficacy, hope, resilience and optimism. It is scored on a six point Likert scale, ranging from 1 ('strongly disagree') to 6 ('strongly agree'). Scores from the PCQ had evidence of adequate reliability ranging from 0.67 to 0.90 (Görgens-Ekermans \& Herbert, 2013; Simons \& Buitendach, 2013). The internal reliability of scores from the PCQ in the present sample was 0.89 .

The ALQ comprises 16 items to measure four subscales of authentic leadership, namely self-awareness, relational transparency, balanced processing and internalised moral perspective (Luthans \& Avolio, 2003). It is scored on a fivepoint Likert scale with the item responses ranging from 0 ('not at all') to 4 ('frequently'). A previous South African study using a healthcare industry sample reported reliability coefficients of 0.93 for scores from the ALQ (Stander, De Beer, \& Stander, 2015). The internal reliability of scores from the ALQ in the present study was 0.95 .

\section{Data analysis procedure}

Descriptive and inferential statistics were used to analyse the data, which include Pearson correlation analysis and multiple 
regression analysis (which was also used for mediation and moderation analysis). SPSS version 24 was employed for the analysis, and the PROCESS macro (Hayes, 2013) was utilised for the mediation and moderation analysis.

\section{Ethical consideration}

Ethical clearance was received from the University of the Western Cape ethics committee (reference number 13/5/36). The information page and informed consent contained in the electronic questionnaire utilised for the data collection at the participating organisation assisted to ensure ethical practice. Firstly, it provided an explanation of the nature and rationale for the research. Secondly, it informed participants that their participation in the research study was voluntary and that they could withdraw from the study at any time prior to submission of their responses. Participants were also informed that their non-participation or withdrawal from the research would not be known to anybody other than themselves and therefore there would be no consequences should they decide not to participate. Thirdly, the information page explained that the responses would be kept anonymous and that it would not be possible, in any way, to trace the responses back to individuals. If the participants wanted to discuss any aspect related to the research, the contact details of both the researcher and the research supervisor were given.

\section{Results}

\section{The relationships between authentic leadership, psychological capital and work engagement}

Authentic leadership and PsyCap respectively correlated 0.314 and 0.578 with work engagement. All correlations were significant at the 0.01 level. The Cronbach's alpha reliability analysis also indicated acceptable reliability, ranging from 0.89 for the PCQ24 to 0.95 for the ALQ. The results are displayed in Table 1.

When comparing the mean item score of the research sample with the norm scales provided in the UWES-17 manual, the healthcare industry sample can be described as - on average having a high level of work engagement. A mean of 4.67-5.53 indicates that respondents feel engaged in their work 'often' to 'very often' or 'once a week' to 'a few times a week'. Similarly, the sample tended to have high levels of PsyCap and scored their leaders as having high levels of authentic leadership.

\section{The mediating role of psychological capital}

Multiple regression analyses were conducted to assess each component of the mediation model. The independent variable for the analyses was authentic leadership $(X)$, the dependent variable was work engagement (Y) and PsyCap was the proposed mediator (M). Firstly, it was found that authentic leadership was positively associated with work engagement $(\beta=0.12, t[2,647]=3.410, p=0.0007)$. It was also found that authentic leadership was positively related to PsyCap $(\beta=0.20, t[2,647]=7.91, p=0.000)$. Lastly, results indicated that the mediator, PsyCap, was positively associated with work engagement $(\beta=0.80, t[2,647]=15.00$, $p=0.0000)$. Because all three of the relationships were significant, mediation analyses were carried out using the bootstrapping method with bias-corrected confidence estimates (Hayes, 2013). The 95\% confidence interval (CI) of the indirect effects was obtained with 5000 bootstrap resamples. Results of the mediation analysis confirmed the mediating role of PsyCap in the relation between authentic leadership and work engagement $(\beta=0.16$; $C I=0.12-0.21$ ). As the relationship between authentic leadership and work engagement remained significant $(\beta=0.12, t[2,647]=3.42$, $p=0.0007)$ when controlling for PsyCap, partial mediation of PsyCap is suggested. Figure 1 provides a display of the results.

\section{The moderating role of psychological capital}

The PROCESS macro was applied to determine the potential moderating effect of a third variable on the relationship between authentic leadership and work engagement ( $X$ and $Y)$. Mean centring was done for all the variables in an effort to reduce multicollinearity. In order to confirm whether the third variable has a moderation effect on the relationship between the two variables ( $X$ and $Y$ ), it must be proven that the nature of this relationship changes as the values of the moderating variable (M) changes, according to Hayes (2013). The variables explained a combined $35.6 \%(F[3,643]=118.63$, $\left.p<0.001, R^{2}=0.3563\right)$ of the variance in work engagement. The detailed results are displayed in Table 2.

From Table 2 it can be seen that both predictors remained statistically significant, with authentic leadership $b=0.12$,

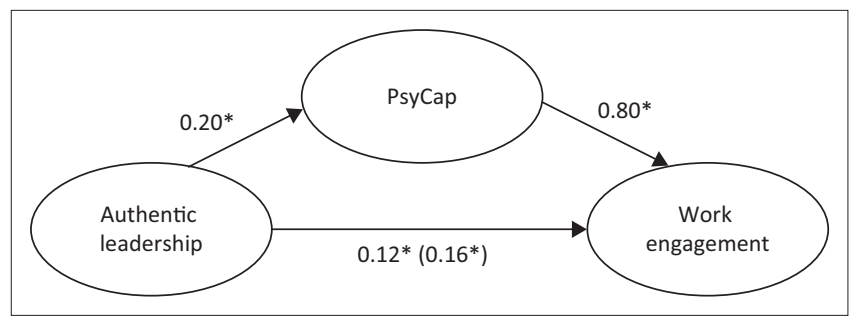

$*, p<0.001$

FIGURE 1: Indirect effect of authentic leadership on work engagement through psychological capital. PsyCap, psychological capital.

TABLE 1: Descriptive statistics and correlations between the variables $(N=647)$.

\begin{tabular}{lccccc}
\hline Variable & $\boldsymbol{M}$ & SD & $\boldsymbol{\alpha}$ & $\mathbf{1}$ & $\mathbf{3}$ \\
\hline 1. Authentic leadership & 2.80 & 0.84 & 0.95 & - & - \\
2. Psychological capital & 4.95 & 0.51 & 0.89 & $0.335^{*}$ & - \\
3. Work engagement & 4.88 & 0.77 & 0.92 & $0.314^{*}$ & - \\
\hline
\end{tabular}

$\mathrm{M}$, mean; SD, standard deviation; $\alpha$, Cronbach's alpha.

$*, p<0.01$. 
TABLE 2: Moderation analysis with psychological capital as moderator $(N=647)$ and work engagement as dependent variable.

\begin{tabular}{lccccc}
\hline Independent variables & $\boldsymbol{\beta}$ & SE & $\boldsymbol{t}$ & $\boldsymbol{p}$ & ULCI \\
\hline Constant & 0.0185 & 0.0254 & 0.7285 & 0.4666 & 0.0314 \\
PsyCap (centred) & 0.7791 & 0.0513 & 15.1756 & 0.0000 & 0.6783 \\
$\begin{array}{l}\text { Authentic leadership } \\
\text { (centred) }\end{array}$ & 0.1236 & 0.0306 & 4.0360 & 0.0001 & 0.0635 \\
$\begin{array}{l}\text { Interaction term } \\
\text { (PsyCap * AL) }\end{array}$ & -0.1289 & 0.0521 & -2.4748 & 0.0136 & -0.2312 \\
\hline
\end{tabular}

$\beta$, standardised regression coefficient; SE, standard error; LLCI, lower level confidence interval; ULCI, upper level confidence interval; AL, authentic leadership; PsyCap, psychological capital.

*, PsyCap is multiplied with authentic leadership (AL) to compute the interaction term.

TABLE 3: Conditional effects of authentic leadership on work engagement at different levels of psychological capital.

\begin{tabular}{lccccc}
\hline Variable & Effect $(\boldsymbol{b})$ & SE & $\boldsymbol{t}$ & $\boldsymbol{p}$ & ULCI \\
\hline Low PsyCap & 0.1894 & 0.0404 & 4.6889 & 0.000 & 0.1101 \\
Average (M) PsyCap & 0.1236 & 0.0306 & 4.0361 & 0.0001 & 0.2688 \\
High PsyCap & 0.0578 & 0.0407 & 1.4195 & 0.1562 & -0.0222 \\
\hline
\end{tabular}

Effect (b), unstandardised simple slope; SE, standard error; $t$, $t$-statistic; $p, p$-value; LLCI, lower level confidence interval; ULCI, upper level confidence interval; $\mathrm{M}$, mean; PsyCap, psychological capital.

$t(643)=4.04, p=0.00$ and PsyCap $b=0.78, t(643)=15.18$, $p=0.00$. In other words, for every one unit increase in authentic leadership, there is a 0.12 increase in work engagement. Similarly, for every one unit increase in PsyCap there is a 0.78 increase in work engagement. The interaction variable (i.e. PsyCap * authentic leadership is also statistically significant at the $p>0.05$ level $(b=-0.13, t[643]=-2.47, p=0.01)$.

In order to create a better understanding of the moderating effect of PsyCap on the relationship between authentic leadership and work engagement, simple slopes for different levels of PsyCap were investigated. The different PsyCap levels present the mean and plus or minus one standard deviation from the mean. For ease of reference, these categories will be called 'low PsyCap' (mean minus one SD), 'average PsyCap' (mean) and 'high PsyCap' (mean plus one SD). These slopes are presented in Table 3.

From the analysis of the conditional effects of authentic leadership on work engagement at low, average and high levels of PsyCap, it becomes apparent that the effect of PsyCap on the relationship between authentic leadership and work engagement is statistically significant for the low PsyCap $(b=0.19, t[643]=4.69, p=0.00)$ and average PsyCap $(b=0.12, t[643]=4.04, p=0.00)$ groups. However, there is no statistically significant relationship between authentic leadership and work engagement for the high PsyCap group $(b=0.06, t[643]=1.42, p=0.16)$. In other words, every unit of authentic leadership provides an increase of 0.19 in work engagement for those with low PsyCap levels and an increase of 0.12 for those with average PsyCap levels. It therefore seems that the impact of authentic leadership on work engagement decreases as the level of PsyCap increase.

\section{Discussion}

Although no other studies have reported on the mediating role of PsyCap between authentic leadership and work engagement, PsyCap has been found to mediate the relationship between authentic leadership and performance (Wang, Sui, Luthans, Wang, \& Wu, 2014). Avey et al. (2008) stated that employees with higher levels of PsyCap tend to proactively facilitate positive changes in the organisation.
Therefore, it seems that PsyCap is important in facilitating the impact of a positive organisational context on desired workplace outcomes.

Authentic leadership does have a direct influence on work engagement. However, this influence is increased as a result of the mediating role of PsyCap. In practical terms this means that an individual's perception of the authentic leadership behaviours of their leader will influence their level of work engagement. If this individual also has high levels of PsyCap, they may interpret their leader's behaviour more positively. Therefore, there will be an increased influence of such leadership behaviour on their work engagement.

Considering the results of the moderating effect of PsyCap on the relationship between authentic leadership and work engagement found in the present sample, it becomes evident that as the PsyCap levels of respondents increase, the influence of the leader's behaviour on the respondent's level of work engagement becomes less important. Wang et al. (2014) found that a higher level of performance was achieved when a lack of PsyCap was complemented with high levels of authentic leadership. Similar to the findings of the present study, Wang et al. (2014) conclude that the impact or need for authentic leadership is decreased when the employee already has a high level of PsyCap. Wang et al. (2014) stated that PsyCap may have a complementary role to leadership rather than a supplementary role. The supplementary role is the more common approach to leadership where a leader's influence is enhanced by followers' characteristics. Complementary congruity theory (Kiesler, 1983) suggests that leaders and followers coordinate their actions by one party acting dominant and the other then being expected to be submissive (and thus, the leader might not always be the dominant party). Following the thinking of complementary congruity and the classical substitutes for leadership theory, Wang et al. (2014) speculates that follower PsyCap could be viewed as a substitute for authentic leadership.

\section{Practical implications}

The results of the present study indicate that PsyCap explains the biggest unique proportion of the variance in 
work engagement. Hence, for organisations trying to improve the levels of employee work engagement and decrease dependence on leadership intervention, PsyCap development may prove useful. Specifically, individuals with a high level of PsyCap rely on their own PsyCap rather than the authentic behaviours of their leaders in order to improve their work engagement. Therefore, human resource professionals could provide PsyCap training and microinterventions that could impact the level of work engagement in a positive manner. Development activities such as the Psychological Capital Intervention (Luthans et al., 2007; Luthans \& Youssef-Morgan, 2017) could be used as short training sessions. The content could include activities such as goal-setting, generating pathways and options to attain the set goals, considering possible obstacles to attainment of the goal, sharing the goal with other participants and being encouraged through their feedback, and reflection on past successes and stressors to build resilience. Individual coaching and mentoring would also be a viable method to develop PsyCap (Luthans et al., 2007). Novel techniques such as video games and gamification techniques also show promise for the development of PsyCap (Luthans \& Youssef-Morgan, 2017).

\section{Limitations and recommendations}

With regard to methodological choices for future research, it is suggested that longitudinal studies should be conducted to determine the relationships between the variables over time. One of the characteristics of PsyCap and work engagement is that both are state-like in nature. Even though both variables have been shown to be stable over a period of time, longitudinal research is needed to determine whether there is also stability in the relationships between the variables. Allesandri et al. (2018) reported that more than two waves of data may be needed to improve the helpfulness of the findings.

Furthermore, hierarchical levels of analysis can also be utilised. This could include studying the leadership impact on work engagement by utilising nested models that would measure the impact of a specific leader's behaviour on the work engagement of employees. Moreover, studying the psychometric variables at the group and organisational levels can also offer valuable insights to understanding positive employee behaviour in the workplace.

In addition, the definition of authentic leadership (Luthans \& Avolio, 2003) indicates that authentic leadership draws from a highly developed organisational context. This context includes the organisation's vision, strategy and culture, which act as antecedents of authentic leadership development on organisations. In the case where the organisational culture is negative, with abusive leadership and dominant organisational politics, authentic leadership is unlikely to develop and thrive (Luthans \& Youssef-Morgan, 2017). Thus, the influence of the organisational context should be considered in future studies on authentic leadership.

\section{Conclusion}

In the present study, the role of PsyCap in the relationship between authentic leadership and work engagement was explored. PsyCap explained a large proportion of the variance in work engagement for all employees. For individuals with high levels of PsyCap, the authentic leadership behaviours they perceived in their leader did not have a significant influence on their levels of work engagement. Thus, the development of hope, efficacy, resilience and optimism in employees may be a viable option to improve levels of employee work engagement.

\section{Acknowledgements}

This work is based on research supported in part by the National Research Foundation (NRF) of South Africa. Any opinions, findings and conclusions or recommendations expressed in this material are those of the authors and the NRF does not accept any liability in this regard. This work is based on the PhD work of the first author: Du Plessis (2014). The authors also acknowledge the research organisation for their support in facilitating the data collection.

\section{Competing interests}

The authors declare that they have no financial or personal relationships that may have inappropriately influenced them in writing this article.

\section{Authors' contributions}

M.D.P. was responsible for all writing, data gathering and data analysis. A.B.B. was the supervisor of this $\mathrm{PhD}$ research study and reviewed the draft and final version of the manuscript.

\section{References}

Alessandri, G., Consiglio, C., Luthans, F., \& Borgogni, L. (2018). Testing a dynamic model of the impact of psychological capital on work engagement and job performance. Career Development International, 23(1), 33-47. https://doi. org/10.1108/CDI-11-2016-0210

Avey, J. B., Reichard, R. J., Luthans, F., \& Mhatre, K. H. (2011). Meta-analysis of the impact of positive psychological capital on employee attitudes, behaviors and performance. Human Resource Development Quarterly, 22(2), 127-152. https:// doi.org/10.1002/hrdq.20070

Avey, J. B., Wernsing, T. S., \& Luthans, F. (2008). Can positive employees help positive organizational change? Impact of psychological capital and emotions on relevant attitudes and behaviors. The Journal of Applied Behavioral Science, 44(1), 48-70. attitudes and behaviors. The Journal of Applied
https://doi.org/10.1177/0021886307311470

Avolio, B. J., \& Gardner, W. L. (2005). Authentic leadership development: Getting to the root of positive forms of leadership. Leadership Quarterly, 16, 315-338. https://doi.org/10.1016/j.leaqua.2005.03.001

Avolio, B. J., Gardner, W. L., Walumbwa, F. O., Luthans, F., \& May, D. R. (2004). Unlocking the mask: A look at the process by which authentic leaders impact follower attitudes and behaviors. The Leadership Quarterly, 15, 801-823. https:// doi.org/10.1016/j.leaqua.2004.09.003

Avolio, B. J., \& Mhatre, K. H. (2012). Advances in theory and research on authentic leadership. In K. S. Cameron, \& G. M. Spreitzer (Eds.), The Oxford handbook of positive organizational scholarship (pp. 773-783). New York: Oxford University Press.

Avolio, B. J., Walumbwa, F. O., \& Weber, T. J. (2009). Leadership: Current theories, research and future directions. Annual Review of Psychology, 60, 421-449. https://doi.org/10.1146/annurev.psych.60.110707.163621

Bakker, A. B. (2009). Building engagement in the workplace. In R. J. Burke \& C. L. Cooper (Eds.), The peak performing organization (pp. 50-72). Oxon, UK: Routledge.

Bakker, A. B., \& Albrecht, S. (2018). Workengagement: Current trends. Career Development International, 23(1), 4-11. https://doi.org/10.1108/CDI-11-2017-0207 
Bakker, A. B., \& Demerouti, E. (2008). Towards a model of work engagement. Career Development International, 12, 209-223. https://doi.org/10.1108/136204308 10870476

Bakker, A. B., Demerouti, E., \& Sanz-Vergel, A. I. (2014). Burnout and work engagement: The JD-R approach. Annual Review of Organizational Psychology and Organizational of Behaviour, 1(1), 389-411. https://doi.org/10.1146/annurevorgpsych-031413-091235

Bargagliotti, L. (2012). Work engagement in nursing: A concept analysis. Journal of Advanced Nursing, 68(6), 1414-1428. https://doi.org/10.1111/j.1365-2648. 2011.05859.x

Cameron, K. S., \& Spreitzer, G. M. (2012). Introduction: What is positive about positive organizational scholarship? In K. S. Cameron, \& G. M. Spreitzer (Eds.), The Oxford handbook of positive organizational scholarship (pp. 1-14). New York: Oxford University Press.

Chan, A. Y. L. H., Hannah, S. T., \& Gardner, W. L. (2005). Veritable authentic leadership Emergence, functioning, and impacts. In W. L. Gardner, B. J. Avolio, \& F. O. Walumbwa (Eds.), Authentic leadership theory and practice: Origins, effects, and development (Vol. 3, pp. 3-41). New York: Elsevier.

Conger, J. A., \& Kanungo, R. N. (1998). Charismatic leadership in organizations. Thousand Oaks, CA: Sage.

Deci, E. L., Connell, J. P., \& Ryan, R. M. (1989). Self-determination in a work organization. Journal of Applied Psychology, 74(4), 580. https://doi.org/10.1037/ 0021-9010.74.4.580

Du Plessis, M. (2014). The relationship between authentic leadership, psychological capital, followership and work engagement. Unpublished PhD dissertation, University of the Western Cape. Retrieved from http://etd.uwc.ac.za/bitstream/ handle/11394/3903/Du\%20Plessis_PHD_2014.pdf?sequence=1\&isAllowed=y

Gallup. (2013). State of the global workplace: Employee engagement insights for business leaders worldwide. Washington, DC: Gallup.

Gardner, W. L., Avolio, B. J., Luthans, F., May, D. R., \& Walumbwa, F. (2005). 'Can you see the real me?' A self-based model of authentic leader and follower development. The Leadership Quarterly, 16, 343-372. https://doi.org/10.1016/j. development. The 2005.03 .003

Giallonardo, L. M., Wong, C. A., \& Iwasiw, C. L. (2010). Authentic leadership of preceptors: Predictor of new graduate nurses' work engagement and job satisfaction. Journal of nursing management, 18(8), 993-1003. https://doi. satisfaction. Journal of nursing manage
org/10.1111/j.1365-2834.2010.01126.x

Görgens-Ekermans, G., \& Herbert, M. (2013). Psychological capital: Internal and external validity of the Psychological Capital Questionnaire (PCQ-24) on a South African sample. SA Journal of Industrial Psychology, 39(2), 12. https://doi. African sample. SA Journal
org/10.4102/sajip.v39i2.1131

Harter, J., \& Adkins, A. (2015). What great managers do to engage employees. Harvard Business Review. Retrieved from: https://hbr.org/2015/04/what-great-managersdo-to-engageemployees

Hayes, A. F. (2013). Introduction to mediation, moderation, and conditional process analysis: A regression-based approach. New York: Guilford Press.

Hobfoll, S. E. (2002). Social and psychological resources and adaptation. Review of General Psychology, 6(4), 307-324. https://doi.org/10.1037/1089-2680.6. 4.307

Hsieh, C-C., \& Wang, D-S. (2015). Does supervisor-perceived authentic leadership influence employee work engagement through employee-perceived authentic leadership and employee trust? The International Journal of Human Resource Management, 26(18), 2329-2348. https://doi.org/10.1080/09585192.2015.1025 234

Huang, L., \& Luthans, F. (2014). Towards better understanding of the learning goal orientation-creativity relationship: The role of positive psychological capital. Applied Psychology, 64(2), 444-472. https://doi.org/10.1111/apps.12028

Ilies, R., Morgeson, F. P., \& Nahrgang, J. D. (2005). Authentic leadership and eudaemonic well-being: Understanding leader-follower outcomes. The Leadership Quarterly, 16, 373-394. https://doi.org/10.1016/j.leaqua.2005.03.002

Jensen, S. M., \& Luthans, F. (2006). Entrepreneurs as authentic leaders: Impact on employees' attitudes. Leadership and Organizational Development Journal, 27(7), 646-666. https://doi.org/10.1108/01437730610709273

Kahn, W. A., \& Heaphy, E. D. (2014). Relational context of personal engagement at work. In C. Truss, R. Delbridge, E. Soane, K. Alfes, \& A. Shantz (Eds.), Employee engagement in theory and practice (pp. 163-179). London, UK: Routledge.

Kiesler, D. J. (1983). The 1982 interpersonal circle: A taxonomy for complementarity in human transactions. Psychological Review, 90(3), 185. https://doi.org/10.1037/ 0033-295X.90.3.185

Laba, K., \& Geldenhuys, M. (2016). Psychological availability and work engagement: The moderating role of sex and race. Journal of Psychology in Africa, 26(2), 107-112. https://doi.org/10.1080/14330237.2016.1163888

Luthans, F. (2002). Positive organizational behavior: Developing and managing psychological strengths. Academy of Management Executive, 16, 57-75.

Luthans, F., \& Avolio, B. J. (2003). Authentic leadership: A positive developmental approach. In K. S. Cameron, J. E. Dutton, \& R. E. Quinn (Eds.), Positive organizational scholarship: Foundations of a new discipline (pp. 241-258). San Francisco, CA Berrett-Koehler.

Luthans, F., Avolio, B. J., Avey, J. B., \& Norman, S. M. (2007). Positive psychological capital: Measurement and relationship with performance and satisfaction. Personnel Psychology, 60, 541-572. https://doi.org/10.5465/ame.2002.6640181

Luthans, F., Luthans, K. W., \& Luthans, B. C. (2004). Positive psychological capital: Beyond human and social capital. Business Horizons, 47(1), 45-50. https://doi. org/10.1016/j.bushor.2003.11.007
Luthans, F., Norman, S. M., Avolio, B. J., \& Avey, J. B. (2008). The mediating role of psychological capital in the supportive organizational climate-employee performance relationship. Journal of Organizational Behavior, 29(2), 219-238. performance relationship. Journ
https://doi.org/10.1002/job.507

Luthans, F., Youssef, C. M., \& Avolio, B. J. (2007). Psychological capital: Developing the human capital edge. Oxford, England: Oxford University Press.

Luthans, F., \& Youssef-Morgan, C. M. (2017). Psychological Capital: An evidence-Based positive approach. Annual Review of Organizational Psychology and Organizational Behavior, 4, 339-366. https://doi.org/10.1146/annurev-orgpsych032516-113324

Mäkikangas, A., Feldt, T., Kinnunen, U., \& Mauno, S. (2013). Does personality matter? Research on individual differences in occupational well-being, In A. B. Bakker, (Ed.), Advances in positive organizational psychology (Vol. 1, pp. 107-143). Bingley: Emerald.

Maslach, C., Schaufeli, W. B., \& Leiter, M. P. (2001). Job burnout. Annual Review of Psychology, 52, 397-422. https://doi.org/10.1146/annurev.psych.52.1.397

Mostert, K., \& Rathbone, A. D. (2001). Work characteristics, work-home interaction and engagement of employees in the mining industry. Management Dynamics, 16(2), 36-52.

Munyaka, S. A., Boshoff, A. B., Pietersen, J., \& Snelgar, R. (2017). The relationships between authentic leadership, psychological capital, psychological climate, team commitment and intention to quit. SA Journal of Industrial Psychology/SA Tydskrif vir Bedryfsielkunde, 43, a1430. https://doi.org/10.4102/sajip.v43i0.1430

Norman, S. M., Avey, J. B., Nimnicht, J. L., \& Pigeon, N. G. (2010). The interactive effects of psychological capital and organizational identity on employee organizational citizenship and deviance behaviours. Journal of Leadership and OrganizationStudies, 17(4),380-391.https://doi.org/10.1177/1548051809353764

Penger, S., \& Černe, M. (2014). Authentic leadership, employees' job satisfaction, and work engagement: A hierarchical linear modelling approach. Economic Research, 27(1), 508-526. https://doi.org/10.1080/1331677X.2014.974340

Petersen, K. (2015). Authentic leadership and unit outcomes: Additive and interactive contributions of climate and psychological capital. PhD Thesis, Bellevue University of Bellevue, NE.

Pillai, R., \& Meindl, J. R. (1998). Context and charisma: A 'meso' level examination of the relationship of organic structure, collectivism, and crisis to charismatic leadership. Journal of Management, 24, 643-671.

Rego, A., Sousa, F., Marques, C., \& Pina e Cunha, M. (2012). Authentic leadership promoting employees' psychological capital and creativity. Journal of Business Research, 65(3), 429-437. https://doi.org/10.1016/j.jbusres.2011.10.003

Rich, B. L., LePine, J. A., \& Crawford, E. R. (2010). Job engagement: Antecedents and effects on job performance. Academy of Management Journal, 53(3), 617-635. https://doi.org/10.5465/amj.2010.51468988

Robertson, I. T., \& Cooper, C. L. (2010). Full engagement: The integration of employee engagement and psychological well-being. Leadership \& Organization Development Journal, 31(4), 324-336. https://doi.org/10.1108/01437731011043348

Rothbard, N. P., \& Patil, S. V. (2012). Being there: Work engagement and Positive Organizational Scholarship. In K. S. Cameron, \& G. M. Spreitzer (Eds.), The Oxford handbook of positive organizational scholarship (pp. 56-69). New York: Oxford University Press.

Rothmann, S. (2017). Employee engagement In L G Oades, M. Steger, A. DelleFave, \& J. Passmore (Eds.), The Wiley-Blackwell handbook of the psychology of Fave, \& J. Passmore (Eds.), The Wiley-Blackwell handbook of the psychology of
positivity and strengths-based approaches at work, (pp. 317-341). Wiley: positivity and
Chichester.

Schaufeli, W. B., \& Bakker, A. B. (2003). UWES Utrecht Work Engagement Scale: Preliminary manual (Version 1). Utrecht University: Occupational Health

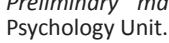

Seligman, M. E. P. (2011). Flourish: A new understanding of happiness and wellbeing - and how to achieve them. London, UK: Nicolas Brealey.

Seligman, M. E. P., \& Csikszentmihalyi, M. (2000). Positive psychology: An introduction American Psychologist, 55, 5-14. https://doi.org/10.1037/0003-066X.55.1.5

Simons, J. C., \& Buitendach, J. H. (2013). Psychological capital, work engagement and organisational commitment amongst call centre employees in South Africa. SA Journal of Industrial Psychology, 39(2), 12. https://doi.org/10.4102/sajip. v39i2.1071

Snyder, C. R., Irving, L. M., \& Anderson, J. R. (1991). Hope and health. Handbook of Social and Clinical Psychology: The Health Perspective, 162, 285-305.

Sparrowe, R. T. (2005). Authentic leadership and the narrative self. The Leadership Quarterly, 16(3), 419-439. https://doi.org/10.1016/j.leaqua.2005.03.004

Stander, F. W., De Beer, L. T., \& Stander, M. (2015). Authentic leadership as a source of optimism, trust in the organisation and work engagement in the public health care sector. SA Journal of Human Resource Management, 13(1), 12. https://doi. org/10.4102/sajhrm.v13i1.675

Storm, K., \& Rothmann, S. (2003). A psychometric analysis of the Utrecht Work Engagement Scale in the South African police service. SA Journal of Industria Psychology, 29(4), 62-70. https://doi.org/10.4102/sajip.v29i4.129

Sweetman, D., Luthans, F., Avey, J. B., \& Luthans, B. C. (2011). Relationship between positive psychological capital and creative performance. Canadian Journal of Administrative Sciences/Revue Canadienne des Sciences de l'Administration, 28(1), 4-13. https://doi.org/10.1002/cjas.175

Walumbwa, F. O., Avolio, B. J., Gardner, W. L., Wernsing, T. S., \& Peterson, S. J. (2008). Authentic leadership: Development and validation of a theory-based measure. Journal of Management, 34, 89-126. https://doi.org/10.1177/ 0149206307308913 
Wang, H., Sui, Y., Luthans, F., Wang, D., \& Wu, Y. (2014). Impact of authentic leadership on performance: Role of followers' positive psychological capital and relational job.1850

Woolley, L., Caza, A., \& Levy, L. (2011). Authentic leadership and follower development: Psychological capital, positive work climate, and gender. Journal of Leadership \& Organizational Studies, 18(4), 438-448. https://doi.org/10.1177/ 1548051810382013
Xanthopoulou, D., Bakker, A. B., Demerouti, E., \& Schaufeli, W. B. (2009). Work engagement and financial returns: A diary study on the role of job and personal resources. Journal of Occupational and Organizational Psychology, 82, 183-200. https://doi.org/10.1348/096317908X285633

Youssef, C. M., \& Luthans, F. (2012). Psychological Capital: Meaning, findings and future directions. In K. S. Cameron, \& G. M. Spreitzer (Eds.), The Oxford handbook of positive organizational scholarship (pp. 17-27). New York: Oxford University Press. 